\title{
IDENTIFICATION OF $X$ GENE MUTATIONS, GENOTYPE AND SUBGENOTYPE OF HEPATITIS B VIRUS (HBV)
}

\author{
Fatimawali $^{1}$, Billy Kepel ${ }^{1}$, Sitti Romlah ${ }^{2}$, Catur Riany ${ }^{2}$, Debbie Retnoningrum ${ }^{2}$
}

\author{
1Faculty of Medicine Sam \\ Ratulangi University, \\ Kampus Unsrat, Bahu \\ Manado, 95115, Indonesia \\ 2School of Pharmacy \\ Bandung Technology \\ Institute, Jl. Tamansari 64, \\ Bandung, Jawa Barat 40116, \\ Indonesia
}

Submitted: 05-06-2014 Revised: 08-08-2014

Accepted: 15-09-2014

${ }^{*}$ Corresponding author Fatimawali

Email :

fatimawali_umar@yahoo.com

\begin{abstract}
Infection of hepatitis B virus (HBV) is a global health problem, including in Indonesia. There are currently an estimated 2 billion people worldwide are infected with $\mathrm{HBV}$, about $75 \%$ of them are in Asia and 350 million of them will develop into chronic hepatitis $B$. Factors that influence the development of chronic hepatitis B into liver carcinoma include $x$ gene mutation, HBV genotype and subgenotype. This research aims to identify $x$ gene mutation, genotype and subgenotype of HBV infecting hepatitis B patients in Manado associated with the onset of liver carcinoma. HBV DNAs were isolated from blood samples of 30 hepatitis B patients. $X$ gen was amplified using nested PCR with predesigned primer pairs. Amplified DNA fragments were electrophoresed in $1.5 \%$ agarose and visualized under UV. DNA fragments were then separated and purified using Qiagen column, then sequenced to determine their nucleotide sequences of $x$ gene. Amino acid of $x$ protein were deduced from nucleotide sequence of $x$ gene and used as basic to determine HBV genotype and subgenotype. $X$ protein was aligned with those similar protein with the same subgenotype retrieved from GenBank to determine if there was a mutation at amino acid. The mutated $x$ protein were compared with other mutation found in $x$ protein in other literatures associated with the onset of liver carcinoma. Genotype and subgenotype of HBV isolated from blood samples of 10 patients was detected and showed that five patients were infected with B genotype HBV (2 patients were infected with B2 subgenotype, 2 patients with B3 subgenotype and 1 patient with $\mathrm{B} 9$ subgenotype). The rest of 5 patients were infected with $\mathrm{C}$ genotype HBV (1 patient with $\mathrm{C} 1$ subgenotype, 2 patients with C2 subgenotype, and 2 patients with C5 subgenotype). The mutation in $x$ protein is related significantly to the clinical severity of the liver and hepatocellular carcinoma (HCC), ie V5L in subgenotype C2, and I127T and H94Y in subgenotype $\mathrm{C} 5$.
\end{abstract}

Key words: HBV, genotype-subgenotype, $x$ protein, liver carcinoma, Manado

\section{INTRODUCTION}

Hepatitis B infection is caused by the hepatitis B virus (HBV). This disease can cause acute and chronic hepatitis B. Chronic hepatitis $\mathrm{B}$ may progress to liver cirrhosis and liver carcinoma (hepatocellular carcinoma, HCC). With more than 500,000 events predicted in 2000, HCC is the most frequent malignant tumor in the world and the rate of incidence is increasing in many countries including Indonesia. Although it is the most common cancer found in patients, with rank fifth for the amount, HCC is the third leading cause of death after lung and stomach cancer (Lupberger and Hildt, 2007).

Hepatitis B virus is a part of the Hepadnaviridae family of viruses. This virus consists of nucleocapsid and external envelope that mainly harbors three surface antigens HBsAg that play a role in the diagnosis of $\mathrm{HBV}$ infection. Its nucleocapsid contains core antigen of hepatitis B ( $\mathrm{HBcAg})$, reverse transcriptase, viral genome, and cell protein. The genome consists of circular DNA molecule with the size of $3200 \mathrm{bp}$. S gene encodes for three antigens namely pre-S1, pre-S2, and S, 
which are the variation of $\mathrm{HBsAg}$. Proteins encoded by pre-core (pre-C)/core (C) genes undergo post-translational modification to produce $\mathrm{Be}$ antigen ( $\mathrm{HBeAg}$ ), which is a seromarker for high levels of viral replication. Core gene encodes for $\mathrm{HBcAg}$, a major structural protein of nucleocapsid. $X$ gene encodes for hepatitis $\mathrm{B} \times$ antigen ( $\mathrm{HBxAg}$ ) which is known as powerful cell transactivator and viral gene. Several interactions with cell proteins have been proposed as $\mathrm{HBxAg}$ target (Baumert et al., 2007).

Research on HCC has a lot of concern especially in relation to risk factors both in terms of the virus and its host. Several studies have identified factors associated with HBV as a predictor of the emergence of HCC in patients with chronic hepatitis B. An example is seropositivity $\mathrm{HBeAg}$. High content of virus and HBV genotype $\mathrm{C}$ are interrelated predictors for HCC. In addition, HBV DNA content is also correlated with the risk of cirrhosis development. These factors are interrelated, for example, patients with genotype $\mathrm{C}$ is more often had HBeAg-positive compared with patients with genotype $\mathrm{B}$. Another genetic character also recently been identified. Precore and basal core promoter (BCP) mutant are the most common in HBV mutants. Double mutations in BCP A1762T/G1764A have been reported related to development of HCC (Lupberger and Hildt, 2007). The area which control the transcription of $\mathrm{BCP}$ and precore core region overlaps with a $x$ gene. Mutations in the precore region prevents the synthesis of $\mathrm{HBeAg}$, but still allows the formation of a virus. G1986A mutation causes a premature stop codon, and is commonly found in HBV that infects $\mathrm{HBeAg}$ negative patients and some fulminant hepatitis B. Double mutation A1762T/G1764A decrease the expression of $\mathrm{HBeAg}$ but increase the replication of HBV genome (Yang et al. 2008). One study showed that the incidence of HCC was higher in genotype $C$ than genotype $B$, with variant precore G1896 (wild-type) higher than G1896A variant, and the BCP double mutation A1762T/G1764A is significantly higher compared with the wild-type variant of the BCP. The highest risk occurs when infected with $\mathrm{HBV}$ genotype $\mathrm{C}$ and the wild-type variant for the precore 1896, and mutant for BCP variants A1762T/G1764A (Yang et al., 2008). Mutations of PreS VHB C1653T, T1753V, and A1762T/G1764A have been reported to have risk factors associated with HCC in a metaanalysis. These mutations are considered as a mechanism to avoid themselves from host immune system and can affect the potential inchogenic chronic hepatitis $\mathrm{B}$ disease.

$\mathrm{HBV} x$ gene is the gene with the smallest size, but encodes a multifunctional protein of 154 amino acids, with amino end containing antiapoptotic domain/negative regulation, and carboxyl end containing proapoptotic/ transactivation. This gene also appears to be associated with the modulation of various cell functions that cause HCC. One study showed that mutations that occur in $\mathrm{HBx} 131, \mathrm{HBx} 130$, $\mathrm{HBx} 5, \mathrm{HBx} 94$, and $\mathrm{HBx} 38$ were commonly found in patients with HCC. Of these mutations, double mutation ( $\mathrm{HB} \times 130 / \mathrm{HB} \times 131)$ and triple mutation $\mathrm{HB} \times 5 / \mathrm{HB} \times 130 / \mathrm{HB} \times 131$ were very significantly found in HCC patients. A double and a triple mutation increase the risk of HCC, with 3.75 times and 5.34 times respectively. $\mathrm{HBx} 5$ mutation in HBV genotype C2 appears to be a risk factor for development of HCC and can be used to predict the clinical impact of chronic HBV infection (Lee et al. 2011).

Frequency of $x$ protein mutation in patients with more severe hepatitis B, hepatocellular carcinoma $(3.6 \%)$ or liver cirrhosis (4\%) was always significantly higher than patients with less severe forms, chronic hepatitis $(2.9 \%)$ or career asymptomatic $(2.1 \%)$, but there was no significant difference in serological status for HBeAg. The six mutations ((V5M/L, P38S, H94Y, I127T/N, and $\mathrm{K} 130 \mathrm{M}$ and V131I) affect the six codons, which are known significantly associated with clinical severity. Among these mutations, two types of mutations (V5M / L and K130M and V131I) were found more frequently in patients with $\mathrm{HBeAg}$ negative than patients with HBeAg positive.

This study concludes that there is accumulation of mutations in the $x$ gene, which contribute to the progress of the disease in patients with chronic hepatitis, at least in patients in Korea with genotype C. Particular type of mutation appears to be associated with severe hepatitis such as HCC or liver cirrhosis. 
Type a new mutation (V5M / L) was found to correlate with HCC. This study also shows that the rate of mutations in $x$ gene is associated with the emergence of HCC. Mutation rate in patients with HCC was $3.6 \%$, liver cirrhosis $(4 \%)$, chronic hepatitis $(2.9 \%)$, and only $2.1 \%$ in asymptomatic career (Kim et al., 2008).

Because information about mutations in $x$ gene, genotype and subgenotype of HBV that infect patients with hepatitis $B$ is very important to , the study aims to identify $x$ gene $(x$ protein) mutation, genotype and subgenotype of HBV infecting hepatitis B of some patients in Manado associated with the onset of liver carcinoma.

\section{MATERIALS AND METHODS Materials}

Sterile aquadest , primer HBV_1233_for 5'-CATGCGTGGR (A/G)ACCTTTGTG-3', primer HBVF1_1685_rev 5'-GCCTCAAG GTCGGTCGTT-3', primer HBVF2_1545_for 5'-CTCCCC GTCTGTGCCTTC-3' (1st Base), primer HBVF2_1940_rev 5'-CAGAAGGCAA AAAAGAGA GTAACTC-3' (IDT), $\mathrm{MgCl}_{2}$ (MD Bio), Taq pol (MD Bio), buffer 10x (MD Bio), dNTP 10mM (Vivantis), DMSO, marker DNA 100 bp (MD Bio), marker DNA 1kb (Fermentas), agarose (Promega), glacial acetic acid (Merck), Tris Base (J. T. Barker), EDTA (J. T. Barker), and ethidium bromide (Promega).

\section{Equipments}

Applied biosystem 2720 Thermal Cycler, autoclave (All American Model 25x America), elektrophoreses gel (BioRad), microwave (Goldstar), micropippete (Eppendorf), measuring glass (Pyrex), Erlenmeyer flask (Herma, Pyrex), micropippete tip (Biologix), microtube (Biologix), and digital camera (Canon).

\section{Sample Preparation}

A total of $2 \mathrm{~mL}$ of blood serum sample of 30 patients infected with hepatitis B were taken and put into EDTA tubes and stored at $4^{\circ} \mathrm{C}$ prior to the isolation of HBV DNA. Collected in January until June 2013 , consisting of 15 people each women and men, with age 40-60 years.

\section{Isolation of VHB DNA}

Isolation of HBV DNA was performed in the Clinical Laboratory Pramita Jakarta. The DNA was isolated from patients' serum using High Pure Viral nucleic acid kit (Roche). Virus is lysed by incubating in buffer lysis with proteinase K. Free nucleic acid is bound specifically to the surface of glass fiber with Chaotropic salts. DNA is then washed to remove other impurities and then eluted with a low power salt buffer or water.

\section{Amplification of $x$ gene and electrophoreses \\ Nested PCR was performed on a total of} 30 isolates DNA from serum samples that had been isolated in the Clinical Laboratory Pramita Jakarta. The composition of the first phase of the PCR mixture was : sterile aquadest $17.75 \mu \mathrm{L}$, buffer $2.5 \mu \mathrm{L}, \mathrm{MgCl}_{2} 2 \mu \mathrm{L}$, dNTP 0.5 $\mu$, Primer For 5'-CATGCGTGGR(A/G)ACCT'TTGTG3' $(20 \mathrm{mM}) 05 \mu \mathrm{L}$, Primer Rev $(20 \mathrm{mM}) 0.5 \mu \mathrm{L}$, Taq pol $0.25 \mu \mathrm{L}$, and $1.0 \mu \mathrm{L} \mathrm{DNA} \mathrm{template.} \mathrm{The}$ first PCR conditions were as follows: initial denaturation at $94^{\circ} \mathrm{C}$ for $5 \mathrm{~min}$; denaturation at $94^{\circ} \mathrm{C}$ for $30 \mathrm{sec}$, annealing at $50^{\circ} \mathrm{C}$ for $1 \mathrm{~min}$, extention at $72^{\circ} \mathrm{C}$ for $1 \mathrm{~min}$, repeated as many as 25 cycles; and ended with final extention at $72^{\circ} \mathrm{C}$ for $10 \mathrm{~min}$. The results of the first PCR was diluted 10x, 25x and 100x times and $1 \mu \mathrm{L}$ then was taken to be a template in the second PCR. The PCR mixture and condition were the same with the first PCR with different primers, namely HBV_1233_For and HBVF1_1685_rev to get the first $x$ gene product fragment, and HBVF2_1545_for and HBVF2_1940_rev to get the second $x$ gene product fragment. PCR products were electophoresed in 1.5\% agarose gel and visualized under UV.

\section{Nucleotide Sequence Determination of HBV x Gene}

PCR products were purified from agarose gel by cutting the gel, then purified using Qiagen columns. The nucleotide sequences of the PCR products are determined both directions using the primers used in the second PCR using the authomatic dideoxy method. Determination of the nucleotide sequence of PCR products was performed at Macrogen Inc. (South Korea) 


\section{Determination of HBV genotypes and subgenotype of patients with hepatitis B}

Nucleotide sequence obtained was used as the basis for determining the genotype and subgenotype of hepatitis B virus. Amino acid sequenced was deduced from nucleotide sequence for amino acid-based analysis. Percentage homology to the nucleotide sequence / amino acid sequences deposited in GenBank

(http://www.ncbi.nlm.nih.goc/genbank) and di EMBL (http://www.ebi.ac.uk) was calculated. Phylogeny analysis was also performed to determine the genotype of hepatitis $\mathrm{B}$ virus by first using a multiple alignment program at EBI Clustaw

(http://www.ebi.ac.uk/Tools/msa/clustalw2/) and Clustaw2 (http://www.ebi.ac.uk/Tools/ phylogeny/). Closest evolutionary distance to the sequence deposited in GenBank Data will be understood from this analysis.

\section{Mutation Detection}

The presence of mutation was detected by aligning the nucleotide sequence and amino acid sequence with its wildtype counterpart using ClustalW. Sequence of VHB wildtype subgenotype was retrieved from GenBank (NCBI).

\section{RESULTS AND DISCUSSION Amplification of $X$ gen HBV dan Elektroforesis}

Nested PCR was conducted with twostage PCR. The first PCR was aimed at obtaining intact $\mathrm{x}$ gene and its surrounding with theoretical PCR product of 707 bp (Vincent, 2010). The second round PCR was done to obtain $\mathrm{x}$ gene fragment with theoretical first PCR product of $469 \mathrm{bp}$ and second PCR product of 395 bp (Rini, 2013). Agarose gel electrophoreses showed that PCR product in optimum condition with annealing temperature $50^{\circ} \mathrm{C}$ and $100 \mathrm{x}$ dilution for samples F3, F4, F5, F7, F10, and F28, 25x dilution for samples F17 and F18, and 10x dilution for samples F8 and F9. First fragment of $480 \mathrm{bp}$ and second fragment of $400 \mathrm{bp}$ were obtained as shown in Figure 1.

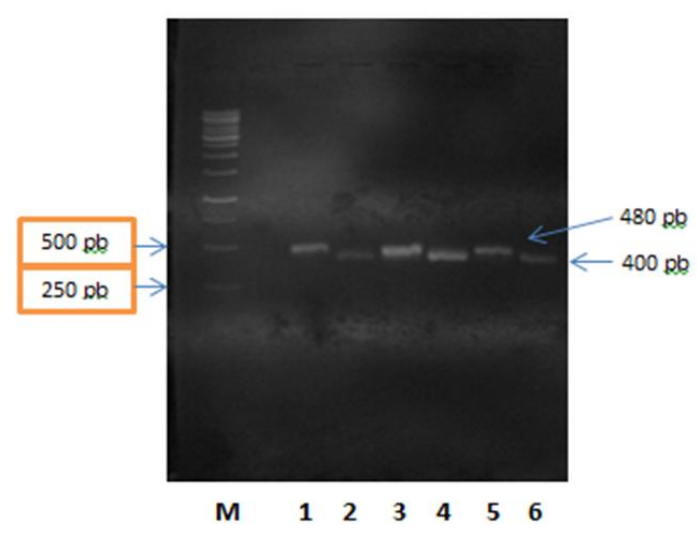

Figure 1. Electroferogram of PCR products of both $\mathrm{x}$ gene with $100 \mathrm{x}$ dilution. $\mathrm{M}=\mathrm{DNA}$ marker, 1 = first fragment from sample F3, $2=$ second fragment from sample F3, $3=$ first fragment from sample F4, $4=$ second fragment from F4, 5 = first fragment from sample F7, 6 = second fragment from sample F7.

$X$ gene of 10 samples were successfully to amplified while the other samples were not successfully even have repeatedly done optimization, this is because the quality of the serum samples were not good and likely due to the length of time of storage of the samples prior to DNA isolation.

\section{BLAST Analysis}

Determination of nucleotide sequence was done in one direction using primer HBV_1233_For for first fragment sample and HBVF2_1545_For for second fragment sample. Nucleotide sequence for both fragments were analysed for each sample and contig was performed to obtain intact $x$ gene . Amino acid sequence was translated based on intact $x$ gene nucleotide sequence to obtain $x$ protein. Blast analysis was conducted to obtain the degree of homology with $x$ protein of $\mathrm{HBV}$ obtained from GenBank.

Having ascertained that the $x$ gene of hepatitis B is amplified, ined. Blast analysis showed that amino acid sequences obtained from the 10 samples are $\mathrm{x}$ protein of hepatitis $\mathrm{B}$ virus. Blast analysis for saits genotype and subgenotype were determmple F4 can be seen in Figure 2. 
Figure 2. Blast analysis of amino acid sequence of $x$ protein Isolate F4 homology with $x$ protein of HBV in GenBank.
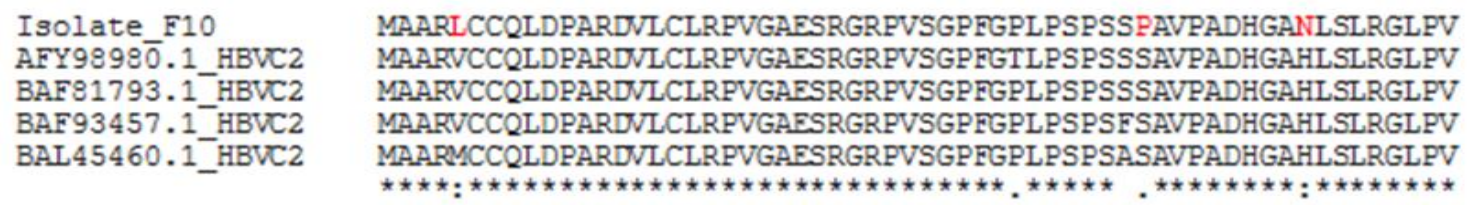

Figure 3. Alignment result of isolate F10 using Clustal W2.

Table I. Analysis of HBV genotype/subgenotype and protein x mutation

\begin{tabular}{cccl}
\hline No & Sampel Code & Genotype/ subgenotype & Protein x mutation \\
\hline 1. & F3 & B/B2 & R87G, E119A, W120E \\
2. & F4 & B/B2 & V45I, P46Q,R87G, N149T \\
3. & F5 & B/B2 & V44A \\
4. & F7 & C/C5 & G22S, S111P, I127T \\
5. & F8 & B/B1 & L37I,T118N, A145T \\
6. & F9 & B/B2 & V45L \\
7. & F10 & C/C2 & V5L, S43P, H52N, H86R, L116V \\
8. & F17 & C/C1 & V30I, V131T \\
9. & F18 & C/C5 & H94Y \\
10. & F28 & C/C1 & T36P, A44T \\
\hline
\end{tabular}

The blast analysis of $x$ protein result showed that 5 samples are $\mathrm{HBV}$ with genotype B, with following details: 1 sample was B1 subgenotype and 4 samples were B2 subgenotype. Five samples are amongst genotype $\mathrm{C}$ with following details: 2 samples were subgenotype C1, 1 sampel was subgenotype $\mathrm{C} 2$, and 2 samples were subgenotype C5. Blast analysis for all samples is shown in table I.

\section{Mutation Analysis}

Amino acid sequence of $\mathrm{HBV} \times \mathrm{x}$ protein was aligned with their counterpart to detect any mutation in its gene. Alignment result of sample F10 with its HBV wildtype subgenotype
C2 is shown in Figure 3. The same workflow was performed on all amino acid sequences, in order to obtain genotype, subgenotype, and mutation data in each sample, as shown in table I.

Some mutations have been found on HBV samples. The mutations found, however, most of them have never been confirmed about its relation to the increased risk of liver cancer. Mutation of each sample is shown at table I. Red writings are mutation related to clinical severity of the liver and liver carcinoma.

Referring to the genotype of hepatitis B virus infecting patients, the same number of patients infected with HBV genotype B and C shows that prevalence of genotype $\mathrm{C}(50 \%)$ is 
high enough, not much different from that found by Mulyanto et al. (2009) that 10 out of 14 patients infected by HBV, were infected with genotype C. Wang et al. (2012) showed that infection of genotype $\mathrm{C}$ relatively more frequent causing cirrhosis and liver cancer compared with genotype $\mathrm{B}$.

Genotypic differences also make a difference in response to treatment with IFN $-\alpha$, in which genotype B has a better response to treatment using IFN- $\alpha$ compared to genotype C (Kao et al., 2000; Wai et al., 2007). The same also happens to antiviral treatment with lamivudine, although both types of these genotypes have a risk of mutations that cause drug resistance after administration of treatment more than 1 year (Kao et al., 2002). Thus, the type of HBV genotypes which infects patient needs to be known, as early information on clinical investigation.

This study showed that all HBV-infected patients had mutations in the protein x. Protein $\mathrm{x} H \mathrm{HBV}$ is associated with the pathogenesis of HBV related diseases, especially in hepatocellular carcinomas of chronic patiens. Cohort study showed that mutation of amino acid at position 127, 130 and 131 were associated with liver disease (Barbini et al., 2012). Five types of mutation, i.e V5M/L, P38S, H94Y, I127T/N, dan K130M and V131I which affecting the six codons were found to be related significantly to clinical severity. Among these mutations, three types of mutation namely V5M/L, K130M and V131I were frequently found in patients with negative HBeAG compared to those with positive HBeAD (Kim et al., 2008). Eventhough double or triple mutations were not found in this study, however 3 patients with HBV mutations were linked with an increased risk of liver cancer, namely $\mathrm{V} 5 \mathrm{~L}$ in subgenotype $\mathrm{C} 2$, and H94Y and I127T in subgenotype C5. Mutation V5L in subtype C2 was significantly associated with HCC (Kim et al., 2008). Genotype C2 is a factor, which was independently linked to an increased risk of liver cancer (Cao et al., 2008). Considering most chronically infected patients did not show any symptoms until eventually developed cirrhosis or liver carcinoma (Hann et al., 2007), then the early detection of the genotype / subgenotype and $x$ gene / $\mathrm{x}$ protein mutations needs to be done.

\section{CONCLUSION}

Genotype and subgenotype of HBV isolated from blood samples of $10 \mathrm{HBV}$ infecting hepatitis B patients was detected and showed that five patients were infected with $\mathrm{B}$ genotype HBV (2 patients were infected with B2 subgenotype, 2 patients with B3 subgenotype and 1 patient with B9 subgenotype). The rest of 5 patients were infected with $\mathrm{C}$ genotype HBV (1 patient with C1 subgenotype, 2 patients with $\mathrm{C} 2$ subgenotype, and 2 patients with C5 subgenotype). The mutation in $x$ protein is related significantly to the clinical severity of the liver and hepatocellular carcinoma (HCC), ie V5L in subgenotype $\mathrm{C} 2$, and $1127 \mathrm{~T}$ and $\mathrm{H} 94 \mathrm{Y}$ in subgenotype C5.

\section{ACKNOWLEDGMENT}

The author would like to thank the Ministry of Education and Culture through the Rector of the University of Sam Ratulangi that provide financial assistance for this study by leading research universities 2013.

\section{REFERENCES}

Barbini L., Tadey L., Fernandez S., Bouzas B., Campos R. 2012. Molecular characterization of hepatitis $\mathrm{B}$ virus $\mathrm{X}$ gene in Chronic hepatitis b patients, Virology Journal, open acces, 9:131

Baumert TF., Thimme R., Weizsäcker FV. 2007, Pathogenesis of hepatitis B virus infection, World J Gastroenterol 2007 January 7; 13(1): 82-90

Gunawan VA. 2012. Genotype and Subgenotype Determination of hepatitis B Virus from Patiens by Using Gene Sequence as a Basis for Counseling, Thesis, Sekolah Farmasi ITB Bandung.

Hann HWL. 2007. Hepatitis B Virus Screening and Counseling Strategies for General Practitioners, John Hopkins Advanced Studies in Medicine, 7(15), 476-481.

Kao JH., Wu NH., Chen PJ., Lai MY., Chen, DS., 2000, Hepatitis B Genotypes and The response to Interferon Therapy, $J$. Hepatol, Vol. 33, Issue 6, Pages 998-1002.

Kao JH., Liu CJ., Chen DS. 2002. Hepatitis B viral genotypes and lamivudine resistance. J Hepatol; 36:303-304. 
Kim BJ. 2014. Hepatitis B Virus Mutations Related to Liver Desease Progression of Korean Patients, World Journal of Gastroenterology.

Kim HJ., Park JH., Jee Y., Lee SA., Kim H., et al., 2008. Hepatitis B Virus X Mutations Occurring Naturally Associated With Clinical Severity of Liver Disease Among Korean Patients With Chronic Genotype C Infection, J Med Virol 80:1337-1343

Lee JH., Han KH., Lee JM., Park JH., Kim, HS., 2011, Impact of Hepatitis B Virus (HBV) X Gene Mutations on Hepatocellular Carcinoma Development in Chronic HBV Infection, Clin V accine Immunol., 18(6): 914-921

Liu, S.H., Zhang,C. Gu, J. Yin,Y., He, Xie j., and Cao G. 2008, Associations Between Hepatitis B Virus Mutations and the Risk of Hepatocellular Carcinoma: A MetaAnalysis, J. Natl. Canc. Inst., 101(15), 1066-1082.

Lupberger J., Hildt E., 2007, Hepatitis B virusinduced oncogenesis, World J Gastroenterol. 13(1): 74-81

Mulyanto, Depamede SN., Kiely S., Tsuda F., Ichiyama K., Takahashi M., Okamoto H.
2009. A Nationwide Molecular Epidemiological Study on Hepatitis B Virus in Indonesia: Identification of two novel subgenotypes, B8 and C7, Arch Virol, DOI 10.1007/s00705-009-0406-9.

Rini KR. 2013. Analisis Mutasi Gen $x$ Virus Hepatitis B pada pasien dengan Metode Nested PCR sebagai dasar Konseling, Skripsi, Sekolah Farmasi ITB Bandung.

Wai CT., Chu CJ., Hussain M., Lok ASF. 2007. HBV Genotype B Is Associated With Better Response to Interferon Therapy in $\mathrm{HBeAg}(+)$ Chronic Hepatitis Than Genotype C, J. Hepatology; 36; 1425-1430.

Wang X., Chen Y., Yu D., Zhang W., Qiu C., Xiang G., Dai W., Wu, S. 201., HBV Subgenotype C2 Infection, A1762T/ G1764A Mutations May Contribute To Hepatocellular Carcinoma with Cirrhosis in Southeast China, Iranian J. Publ Health, 41(11), 10-18.

Yang HI., Yeh SH., Chen PJ., Iloeje UH., Jen C.L., et al., 2008, Associations Between Hepatitis B Virus Genotype and Mutants and the Risk of Hepatocellular, J Natl Cancer Inst, 2008;100: 1134 - 1143. 